\title{
The red castle of Castellorizo: the island's strategic significance and the castle's historical representations
}

\author{
M. Zotos \\ Architecture School, National Technical University of Athens, Greece
}

\begin{abstract}
This paper aims to present the Knight's Castle on the island of Castellorizo by analysing its history and construction, thus to compare its current situation with historical references.

In the $14^{\text {th }}$ century, the Knights of St. John reached Castellorizo on their way to Rhodes. The strategic and commercial reasons why the Knights settled on an island far away $(110 \mathrm{~km})$ from their headquarters in Rhodes are going to be analysed thoroughly in this paper.

What remains today from the medieval fortifications on the island, includes a tall tower $(17.5 \times 22 \mathrm{~m})$, surrounded by a well-built outer wall at the north. These fortifications are enhanced by three smaller circular towers: 2 of them placed in the north while the other one is situated east of the big central tower. The central tower is reinforced by a scarpa in the south; an element to be investigated for its existence and chronological construction.

The archaeologist Albert Gabriel having visited the island in 1916 proposed some important representations of the St. Nicolas castle. Specifically, in his representation of the castle, he suggests that the port's fortifications were significantly extended including other constructions (pavillon, passerelle, poterne, courtines) do not currently exist. Gabriel's representation of the castle is going to be compared with its current condition through sketches, old photographs and $3 \mathrm{~d}$ models examining and analysing the evolution of the island's fortifications.

Keywords: medieval fortifications, Castellorizo, Knights of St. John, Alfonso el Magnanimo, Albert Gabriel, donjon, bastion, scarpa.
\end{abstract}




\section{Introduction}

The triangle-shaped island of Megisti covers an area of approximately $888 \mathrm{sq} . \mathrm{km}$, constituting the smallest island of the Dodecanese complex in Southeast Aegean. It is located $110 \mathrm{~km}$ east of Rhodes Island, while it stands in proximity to the Lycian shore (just $2.50 \mathrm{~km}$ ). The island is widely known as Castellorizo. This name derives from the Italian "Castel Rosso" or the French "Château Rouge", meaning the Red Castle.

Since the Hellenistic period, a great amount of military forces took advantage of the island as base of operations, mostly because of its strategic position. Castellorizo has been the center of warfare or a prey for pirates many times in its history. All of the island's conquerors fortified several strategic places. As a consequence, the island is dotted with fortifications of the Hellenistic, roman, byzantine, medieval and modern period. The medieval St. Nicolas Castle on the harbor's entrance, which defines the main subject of this paper, is part of this fortification system.

\section{The current condition of St. Nicolas castle}

The castle stands $46 \mathrm{~m}$ above the sea level, on a rocky promontory between the two main moorages of the island, "Limani" and "Mandraki". Its fortified position provides a strategic intervisibility to the before mentioned anchorages, but also to the main fortification of the island, the "Paleokastro" castle, situated in the mainland $1.6 \mathrm{~km}$ away. Moreover St. Nicolas castle as surrounded by the sea is rendered inaccessible in case of land invasion. On the other hand, the little islet of "Psoradia" on the north protects the fortification in case of naval invasion.

St. Nicolas' fortifications could be divided in three sub-structures:

1. The central tower or the Keep or "Donjon" 2. The bastion on the north of the Donjon 3. The patio or the inner courtyard or "Cour"

The central tower has an approximately square size $(17.50 \times 22.00 \mathrm{~m})$, and a sloping wall (scarpa) encompasses its east, west and south edges. The sloping wall has a height of $7.50 \mathrm{~m}$ and its basement is formed by a raw $(75 \mathrm{~cm}$ height) of vertically positioned, well-finished large stones. There is an entrance in the middle of donjon's north wall, while a small circular tower protects its east side. The Bastion's total dimensions, including the inner courtyard, are $17.50 \times 26.50 \mathrm{~m}$. Two circular towers $(7.50 \mathrm{~m}$ diameter) protect the bastion on its east and west angle. Remnants of walls and arcs demonstrate that the inner courtyard was separated in smaller rooms and cisterns.

Overall, every part of the castle is built of the island's red limestone. The building's angles are constructed with well-finished large stones put in layers. Its construction technique resembles that of the Hellenistic walls. This is obvious by taking into consideration the references for a Hellenistic tower on the St. Nicolas promontory. In fact, there is an inscription on the south of the existing tower verifying the relevance with the Hellenistic construction. Consequently, it's highly possible that the new conquerors of the island used the Hellenistic construction material to build a new fortification. In contradiction with the building's angles, 
the wall's main body is characterized by lower quality masonry of rough-hew stones. Strong, hydraulic mortar attaches all the stone pieces together. Every part of the walls was originally covered with mortar, but the most of the plastering material has currently leached and collapsed.

Today, the Central Tower, the Donjon of the castle, functions as an archaeological site. Visitors can access the tower through a metal ladder on the east. In comparison, the bastion is inaccessible because of dense vegetation and the remnants of collapsed walls.

\section{The Knights Hospitallers on Castellorizo}

According to d'Anglure's [1] reference in 1395, the Knights Hospitallers of St. John built a castle on the remnants of precedent byzantine fortifications on the island of "CastelRosso". It's widely known that by the end of the $13^{\text {th }}$ century, the Knights of St. John of Jerusalem abandoned one by one their possessions in Sacred Places because of the Saracens' invasion. The Acre Castle would become their last fort. In August 1291, after the castle was seized by Khalil Aschraf, Hospitallers fled to Nicosia, Cyprus. However, the Cypriot King resented to their stay on the island. Consequently, the Knights entered into an agreement so as the Byzantine Emperor allowed them to settle on the island of Rhodes, according to Vertot [2]. As Torr [3] supports, the Knights of St. John reached Castellorizo for the very first time, the 22th of June 1309 on their way to Rhodes. The Knights made a little stop over on the island in order to regain their forces before the seizure of Rhodes. In the meantime, Vignolo de Vignoli, Genoese corsair and byzantine fleet's admiral, went to Rhodes in order to pave the way for the island's takeover by Hospitallers according to Picenardi [4, p. 179]. On $15^{\text {th }}$ August 1309, Rhodes became the new residence for the Order of St. John. Castellorizo, Rhodes and Symi were part of the Cibyrrhaeots Theme (administrative district) during the byzantine period. Therefore, the concession of Castellorizo along with Rhodes' settlement seems rationale besides the big distance $(110 \mathrm{~km})$ between the two islands.

Hospitallers could control a large part of Eastern Mediterranean by occupying Castellorizo. The small island situated close to the Lycian shore had a key position on the main naval route to Jerusalem. Moreover, Castellorizo was an advanced harbor in the East, disposing the only safe anchorage for the Christians amid Rhodes and Cyprus. A well-organized fleet could control or at least cause problems in the maritime connections among Levante, Turkey and Greece. Therefore, the Knights by installing a strong fleet at Castellorizo could destabilize the equilibrium in the region. These are the reasons why Castellorizo, constituted a shelter for vessels of any flag (pirate, Venetian, Spanish, French, Italian and English) during its long history.

Without doubt, Castellorizo served perfectly the Knight's sovereignty in the East Mediterranean, during the $14^{\text {th }}$ century. East Mediterranean was the focal point of the conflict between Christianity and Islam from 1309, during the

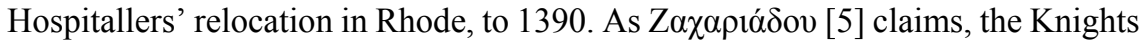
were at war against Emirs of Aidin and Medese and Ottoman Empire on the Anatolian coast. The warfare was conducted in form of naval raids, small or larger 
in scale. Even during a peaceful period, the fights didn't cease but pirates continued to pillage the islands and the ports of Anatolia. Castellorizo could therefore serve as an active base of naval operations for the Knights. The island's safe anchorage could serve a small scale fleet aiming at raids and pillages in Lycia.

The key position of Castellorizo was, thus, one of the main reasons why the Knights built strong fortifications on the island. However, there are no further details about these fortifications. The preserved references do not describe in detail any of the islands castles. There is no written evidence about the form of St. Nicolas castle during the Knights' Period.

\section{When did St. Nicolas castle take its current form?}

On the other hand, important evidence contradicts the St. Nicolas Castle built in its current form by the Knights of St. John in 1309. The Castle of St. Nicolas corresponds to this kind of transitional architecture that evolves between the medieval vertical system and the horizontal bastioned system. Namely, the sloping wall which protects the Central Tower (scarpa) is a construction element which was introduced after the use of gunpowder as the energy source for projectile weapons in the early 15 th century. It aimed mainly at eliminating the canon forces. The sloping walls on the south do not accede therefore, to the reference that the Castle was built by the Knights in 1309 .

During the late $15^{\text {th }}$ century, when all the medieval fortifications were altered in order to confront against canons, Castellorizo constitutes the center of political and commercial negotiations in the East Mediterranean. As Duran Duelt [6] mentions in his extended essay, in October 1450, Pope Nicolas V granted the island to Alfonso el Magnanimo, the king of Aragonia and Catalonia. The principle causation for the Pope to take this decision was the Knight's Sovereignty crisis in the East Mediterranean that resulted directly to the conquest of Castellorizo by the Egyptian fleet in 1440. Alfonso taking advantage of that situation used his diplomatic relation with the Pope in order to reassure the concession of the island. Castellorizo would be very useful for his goals in the Mediterranean during the subsequent years. Alfonso's strategy concerning the East Mediterranean included numerous naval campaigns to the Anatolian and Egyptian coasts. Castellorizo formed therefore, a perfect naval base for the Aragonese galleys.

In accordance with Magnanimo's strategy, admiral, Bernat de Villamari, landed on the island's harbor in late 1450 and started immediately the reconstruction of the old fortifications. The former were severely affected after the Mamluk attacks of 1440 and 1444, as well as because of the subsequent Knights' desertion. As stated in the references of Archivio della Corona de Aragona (ACA) that Duelt [6] published in his essay, Villamari not only restored the existing fortifications but built also a new tower on the port. The construction was significantly delayed because of the Grand Master's tower collapse (according to the ACA) and due to several provisional difficulties. In 1452, all operations were ceased and the blazon of Aragon was placed upon the entrance of the new castle. 
Taking into account the island's importance for Alfonso's dominance in SE Mediterranean, it's highly possible that Villamari built a new modern castle, named "Castel Alfonsi", on the port's promontory, in place of the old one that crumbled (as mentioned in the ACA). Obviously, Alfonso intended to construct fortifications adjusted with the latest improvements of the military techniques of the era in order to repulse any future attack of the Mamluks. This new castle would be, therefore, equipped with the scarpa or the sloping wall, and it probably coincides with the current remnants on St. Nicolas hill.

\section{The visit of Albert Gabriel to the island and his representation of the St. Nicolas castle}

\subsection{The reason why Gabriel visited the island}

In comparison with the poor evidence for the castle's condition during the Knights' and Aragon Period, there are plenty references and drawings made by travelers from the $17^{\text {th }}$ to the $20^{\text {th }}$ century. One of the most remarkable representations of the castle has been made by the famous architect and archaeologist, Albert Gabriel that visited the island in 1916.

All the details about Gabriel's visit in Dodecanese are published in Pinon and Erdur's [7] book on pages 175-180. During Gabriel's visit, Castellorizo was under French occupation. French naval forces, taking advantage of its large and safe port as well as its proximity to the Anatolia coast, transformed the island into a base of operations during the First World War. French Navy was charged with the blockage of Turkish coastline, using the sub-marine defense and taking an important role in counter intelligence. The SIML (Service d'Information de la Marine du Levant) having its headquarters in Port-Said, acquired at the end of 1915 two advanced control centers: the Rouad island in the Syrian Sea and the island Castellorizo that was occupied by $28^{\text {th }}$ December 1915 . Obviously, the island's strategic significance for the East Mediterranean continued even in the $20^{\text {th }}$ century.

In the meanwhile, Gustave Fougères, director of the French Archaeological School in Athens, took a strong decision in favor of the Allies. He was instructed to encourage the school's archeologists to be enlisted in the military forces of the East or the French Navy so as they participate in scientific campaigns in the center of warfare. Consequently, Albert Gabriel, as member of the French Archeological School, departed - companioned to Fougères - for Rhodes in 1915. The warfare was in its peak in the region, since 14 German sub-marines with an operation base in Bodrum were controlling the entire area. During 1915-1916 Gabriel was concerned mainly for the restoration of the "Auberge de France" in Rhode's old town. Alongside, he gained the confidence of French military officers by hiding munitions in the "Auberge de France" and by establishing a monument for the "Indien" shipwreck (French patrol torpedoed by German sub-marine on September 1915). On $5^{\text {th }}$ June 1916, Gabriel visited Castellorizo for the first time. In November 1916 he joined the island's military forces as an interpreter of the French Navy and he stayed on the island until 1917. During his stay on 
Castellorizo, Gabriel conducted several excavations in burial monuments, took photographs and made paintings of the island's harbor, but mainly he developed a friendship with Charles Héderer [8], doctor of French Navy. This doctor wrote an essay in Naval Bulletins of 1923 entitled "L'île du Château-Rouge" in which some of the Albert Gabriel's drawings concerning the castle are published (figure 1).
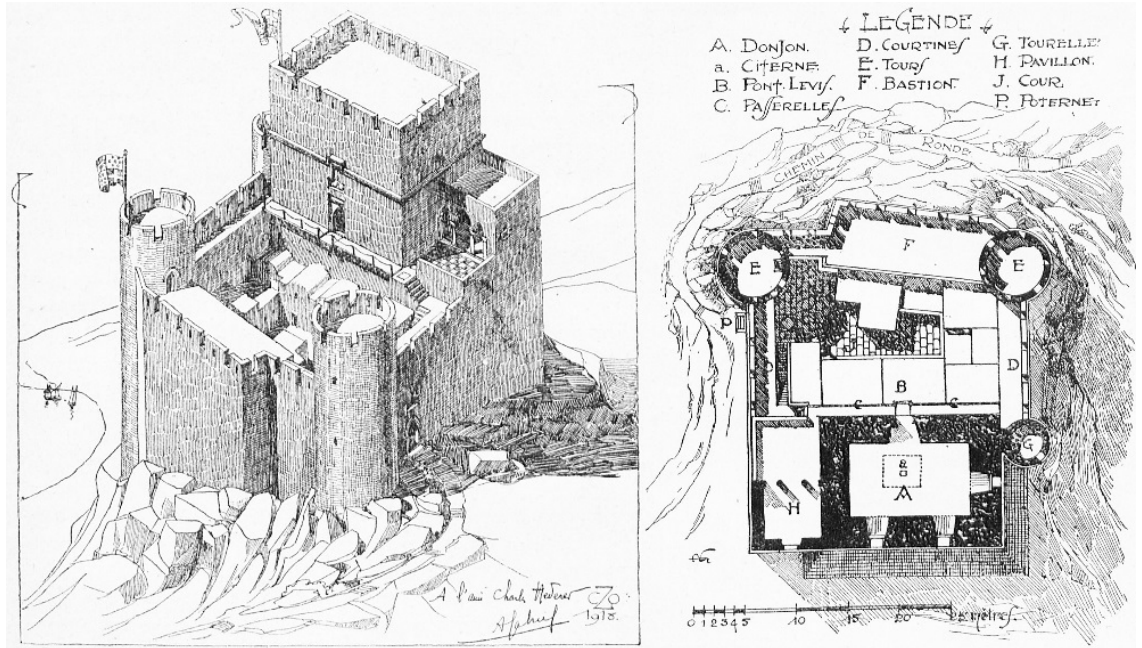

Figure 1: Reconstitution of Château-Rouge (a), plan of Château-Rouge (b), source: Héderer [8].

\subsection{A. Gabriel's representations of the castle in Héderer's [8] book (1916)}

The published drawings include the plan of St. Nicolas Castle, a 3d representation of the castle during the medieval period, and a representation portraying the port's fortifications during the $17^{\text {th }}$ century.

The tower $3 \mathrm{~d}$ representation on page 37 is entitled "Reconstitution du ChâteauRouge" (figure 1 (left)). It is mentioned: "The reconstitution of Château-Rouge is executed by a good friend of mine, Mr. Albert Gabriel, lecturer of Caen School, whose work in Knight's Rhodes represents an excellent monument of Science and Art. The creator was inspired by the castle's remnants, the surveying plans that wouldn't be completed without the help of our valet, Tallec and an old gravure, a masterpiece of Marcian Library published by Mr. Gerola, director of Ravenna Museum."

On page 39 of the essay is found the plan of the St. Nicolas Castle entitled "plan du château rouge" (figure 1 (right)). It is stated: "This plan was designed by Albert Gabriel after completing the surveying sketches of monument's remnants, and it was used as the base-plan for the castle's reconstitution presented above." A legend in the plan indicates all the building elements named and numbered as follows: A. Le Donjon - central tower or Keep and its Citerne - Cistern; B. Le Pont levis - the Drown bridge; C. Le Passerelle - Parapet Walk; D. Les Courtines - Curtain Walls; E. Les Tours - Circular Towers; F. The Bastion; G. Le Tourelle 
- Circular turret; H. Le Pavillon - the Lodge; I. Le Cour - the inner courtyard; K. La Poterne - the main entrance.

The third drawing that is published on page 51 is entitled "Le Château-Rouge au XVIIe Siécle" (figure 2 (up left)). A reference from Dapper on 1703 is indicated in the legend: "... 25 years ago, there was an old castle in Castellorizo that was encircled by double and strong walls...". The fortification's size is designed extensively larger in this drawing. It is observed a new Tower- Keep on the East of the existing one while we can discern a strong wall connecting the two above towers.
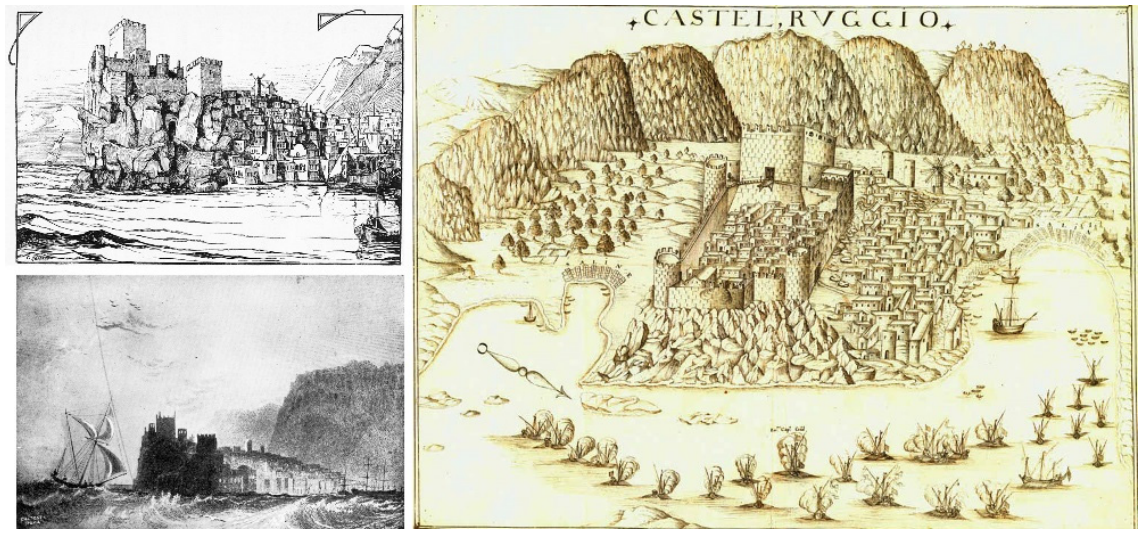

Figure 2: The gravure of 1659 (right), Gabriel's drawing (up left), Carne's drawing (down left).

\subsection{Old drawings that Gabriel consults for his reconstitution of the castle}

As already mentioned, to complete his reconstitution of the castle, Albert Gabriel relied on the survey mapping conducted on field, but also on an old gravure, which G. Gerola published in his essay about Castellorizo, figure 2 (right). This drawing portrays the siege of Castellorizo by the Venetian fleet commanded by admiral Gremonville on 1659 depicting as well, in full detail, The St. Nicolas castle. The gravure is included in the Report of the Army movements during the war between Ottoman Empire and Venetian Republic (1645-1669). The Report, which contains all the battle drawings made until the peace retreat in 1669, is kept in the Marcian Library of Venice.

Carne's representation of Castellorizo harbor, figure 2 (down left), was another drawing that A. Gabriel consulted in order to complete his representation during the $17^{\text {th }}$ century. In his drawing Carne represents two towers in the harbor's promontory.

\subsection{Comparing Gabriel's drawings with the castle's current form}

Important conclusions about the condition and evolution of the castle from medieval times to $20^{\text {th }}$ century could be drawn by analyzing the before mentioned 
Gabriel's drawings. The analysis will be based on the analogy to the existing situation. The description of construction elements will follow the demarcation that Gabriel proposed in his plan of the castle.

\subsubsection{The central tower or the Keep (donjon)}

Gabriel represented the central tower in full detail, designing all its main elements: the scarpa on the south, the central gate on the north and the perimeter walls $(2.8 \mathrm{~m}$ width). The total height of the tower is $16.5 \mathrm{~m}$ and it is crowned by battlements. A blazon above the central gate and a perimeter cornice decorate its walls. Except for the main gate on the north, the Keep is equipped with three gun ports, two on the south and one on the east. Furthermore, the cistern in the lower level of the donjon is represented with a dashed line (figure 1 (right)).

According to a photograph dated back on 1916 (figure 3), a large part of the monument had already collapsed when Gabriel visited the island. We can argue that the architect extracted all the necessary information from the gravure of 1659 , in order to refine his drawings. In the gravure (figure 2 (right)), the tower has its total height and there are battlements on the top. However, it is not evident neither a blazon, perimeter cornice, cistern nor gun ports in the drawing of 1659 . Apparently, Gabriel, being acquainted with medieval architecture, added all the necessary elements with which a medieval castle should be equipped so as to become impassable. That is to say, the gun ports on the south that protects the castle in case of land invasion and the cistern in the Keep that supplies with water the masters of the castle in case of a siege.

Many building elements that A.Gabriel presents in his reconstitution and plan of the castle (figure 1), are preserved until today. For instance, the walls' width in castle's plan coincides with the remnants on the top of the donjon; a part of the blazon stands until now above the main gate.

\subsubsection{The drown bridge (pont levis) and the parapet walk (paserrelle)}

The drown bridge, which protected the central gate of the donjon, does not currently exist. On the contrary, the sloping wall under the gate, which obstructed the access to the donjon when the bridge was picked up, is still evident. However A. Gabriel and the gravure's designer represented the sloping wall extensively larger than it currently appears to be (figures 1,2 ). To be more precise, the sloping wall covers today $3.5 \mathrm{~m}$ on the east and west of the central gate. On the reconstitution of 1916 as well as in the gravure of 1659, the scarpa extends to all the north wall of the donjon. Respectively, the parapet walk that leaded to the gate is currently built of stones and not of timber frames as in the gravure. Gabriel and the drawer of the gravure probably simplified the construction in their drawings by designing a sloping wall covering all the north facade of the tower.

\subsubsection{The curtain walls (les courtines)}

Both the east and west curtain walls of the castle are extant in a very poor condition; (maximum $3 \mathrm{~m}$ above the ground level). Consequently, there is not enough information about the lateral corridors, represented by Gabriel, with a total width of $2 \mathrm{~m}$, based on the curtain walls. In a photograph published by G. Gerola in the essay "Un Picollo Feudo Napoletano nell Egeo (l'isolleta del Castelrosso)" 
(figure 3), it seems that it was preserved a larger part of the east wall in 1916. Nevertheless, there is no corridor preserved. Therefore, Gabriel recalls again the gravure of 1659 (figure 2 (right)), to complete his reconstitution of the castle. In the old drawing, the east corridor, which connects the donjon to the east circular tower, is clearly illustrated.

On the other hand, the remnants of the east wall today have a total width of $1.4 \mathrm{~m}$. which is not sufficient for a $2 \mathrm{~m}$ corridor to be based on. A possible theory could be that the corridor was made of timber or it was based on another lower building that has collapsed.

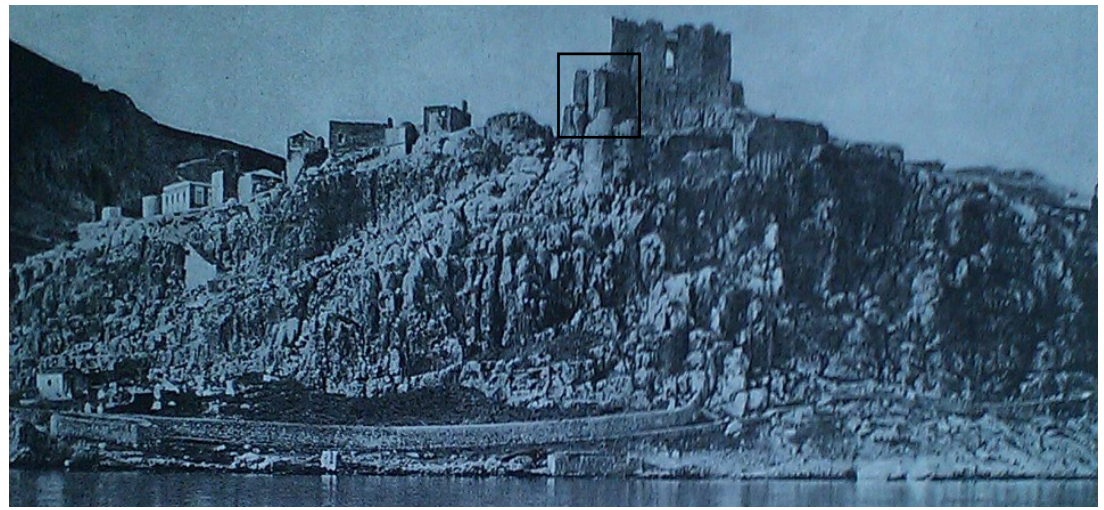

Figure 3: Gerola's photo during 1916, indicating the curtain wall, source: "Un Picollo Feudo Napoletano nell Egeo (l'isolleta del Castelrosso)".

\subsubsection{The circular towers (les tours)}

In Gabriel's reconstitution (figure 1), the two circular towers on the east and on the west are represented in a diameter of $7 \mathrm{~m}$ and having a full height of $32 \mathrm{~m}$ and $23 \mathrm{~m}$ respectively. According to the architect, both of the two towers were equipped with stairwells that leaded from the courtyard's base level to the final level of each tower. In his $3 \mathrm{~d}$ representation (figure $1(\mathrm{left})$ ), it seems that the east tower was connected to the terrace of the bastion. This is an element that derives from the gravure of 1659, where it can be distinguished the relevant gate.

Today the two towers are still in an existence but at a very low level $(5 \mathrm{~m}$ the west one and $7 \mathrm{~m}$ the east one). Consequently, Gabriel's representations of the towers cannot be verified. Besides, the most of its construction elements were being destroyed due to the insertion of gun emplacements on the towers during the First World War.

\subsubsection{The bastion}

In his reconstitution (figure 1), Gabriel recalls the gravure of 1659 and designs the bastion's external walls in a total height of $20 \mathrm{~m}$, with battlements on the top. In the 1659 illustration (figure 2 (right)), merlons with a zigzag edge crowned the external walls. However, Gabriel designs a typical medieval merlon in his reconstitution. 
Bastion's shape and total dimensions of the current condition coincide with Gabriel's survey. The existing external walls of the edifice are preserved in a relatively bad condition, precisely in a height of $5 \mathrm{~m}$ above ground level. During the survey mapping conducted in 2013, the bastion was cleaned out of its dense vegetation revealing in that way new manufacturing data. Specifically, a corrupted aperture appeared on the eastern part of bastion's north wall. It could have originally functioned as a backdoor to the bastion. This aperture is not represented neither in the gravure of 1659 nor in Gabriel's reconstitution of the castle. On the other hand, it was proved that the bastion's lower level was covered by vault. Parts of this structure are preserved until today on the southern part of the bastion.

\subsubsection{The circular turret (la tourelle)}

The small circular turret on the east of the central tower has a diameter of $5 \mathrm{~m}$ and is preserved $5 \mathrm{~m}$ approximately above the ground level. Today (figure 4 (right)), a metal ladder, which is placed in the free space between the donjon and the turret, leads to the upper level of the central tower. In Gabriel's reconstitution (figure 1), the tower has the same diameter but a total height of $13 \mathrm{~m}$ as well as battlements on the top. In the plan drawing, it seems that the turret connects to the donjon. This kind of connection is illustrated in detail in the gravure of 1659 (figure 2 (right)). A two-story construction is presented equipped with little apertures in the north which connects the turret with the donjon. The connection with the donjon implies that the turret functioned as a stair-well leading to the upper floors of the great tower.

On the other hand, according to a photograph of 1916 (figure 4 (left)), a stone staircase attached to the turret on the south, leaded to the donjon's upper floor. This construction is now demolished and replaced by a metal ladder. Consequently, the nature of the stone stairs is ambivalent. They could constitute either a part of the initial construction either a subsequent addition.

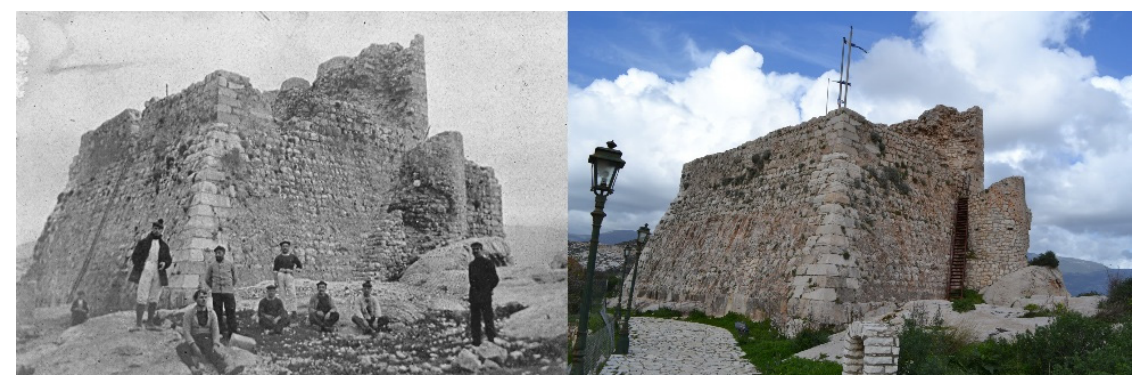

Figure 4: 1916 photo of the castle (left), castle's current condition (right).

\subsubsection{The lodge or pavilion (pavillon)}

According to Gabriel and the gravure of 1659 , the Pavillon was a square plan lodge $(7 \times 7 \mathrm{~m})$ at the east of the central tower. The building had 3 arched apertures at the north and it ended up on blazon level (approximately $7.3 \mathrm{~m}$ height). The lodge's apertures were covered with pointed arcs; an element that would refer to an Ottoman addition. 
Today, there are no traces of any construction on the rocky ground on the east of the donjon where Gabriel places the pavilion in his reconstitution. A stone, which projects out of the scarpa on the south, is the only element implying the existence of a construction at that point.

\subsubsection{The inner courtyard or patio (cour) and the central gate (poterne)}

The inner courtyard, between the donjon and the bastion, is preserved today in very bad condition, as it is fully covered by debris from the castle's collapsed walls. Consequently, evident of any structures could have existed within it, are not highly visible.

Two underground rooms on the south of the bastion are some of the most important elements preserved within the courtyard. The underground structures are covered with vault; they are linked to each other as well to the bastion through arched apertures. The northern room has a rectangle shape $2 \times 4 \mathrm{~m}$. It connects to the bastion on the north and to another smaller room $(1.9 \times 2.5 \mathrm{~m})$ on the south. A trap door connecting to the smaller room on the south implies that the rooms probably functioned as cistern for rainwater harvesting. Besides that, the rooms have such a small height ( $2 \mathrm{~m}$ maximum) that they could not be served for another use. The little aperture on the north suggests the existence of a cistern at the bastion's lower lever as well. However, it's not obvious whether another room covered the cistern's ceiling.

On the other hand, 5 beam boxes are preserved on the east part of the donjon's northern wall, $6.5 \mathrm{~m}$ above courtyard's ground level. The wall boxes have a $30 \mathrm{~cm}$ height and are placed in $70 \mathrm{~cm}$ distance one from the other. It is obvious that the wall boxes hosted the beams of a timber floor. Nevertheless, it is uncertain whether they supported an entire room, or merely a timber parapet walk.

In the gravure of 1659 a great number of little buildings are represented within the inner courtyard, but they barely resemble to the real form of the castle. We can argue that the gravure drawer just replicated the village buildings he observed outside the castle, placing them inside the patio. Having no inner view of the castle, he probably assumed that the buildings inside the castle were similar to the houses on the harbor.

On the contrary, Gabriel tried to represent some buildings in the courtyard corresponding to his survey mapping. For example, he draws a structure that coincides with the two underground rooms mentioned before. Furthermore, he represents some little rooms along the north wall of donjon but also on the east part of the patio in contact with the curtain wall. Unfortunately, it's not evident whether the before mentioned structures were drawn according to the traces preserved in 1916. On the other hand, A.Gabriel recalls to the gravure of 1659 in order to illustrate further elements. For example, he draws the staircase that leads from the patio's ground level to donjon's gate.

The central gate to the castle (poterne) is represented by A.Gabriel on the south of the east circular tower, along the east curtain wall. This is an element that he undoubtedly collected from the gravure of 1659 . Today, there is no proofing element to ensure the gate's exact position. 


\section{Conclusion}

One of the most important conclusions drawn in this article, concerns the exact construction date of the St Nicolas castle. It could be claimed that the original construction of the current remnants, dates back to 1450 when admiral Villamari reached the island. The central tower's sloping wall (scarpa) but also the historical references mentioned before, published by Duelt [6] confirm this proposal. Certainly, the military use of the harbor's promontory initiates at the Hellenistic period and it continues to the medieval ages during Knights' sovereignty. However, the existing structure should be surely dated the $15^{\text {th }}$ century.

On the other hand, it is worth mentioning the accuracy of the Gabriel's drawings. In the middle of the warfare, without the advanced surveying methods of today, the architect managed to portray the medieval monument in complete accuracy. However, the original drawings are not available so we have to refer to their publication in Charles Hederer's book. This fact confines seriously the evolution of the research. In addition, the monument's poor condition limit further the research on the castle's original form.

Nonetheless, the gravure of 1659 and its rendition by Gabriel provide us many elements about each and every separate structure of the castle and their use during the Medieval Ages. Generally, it could be concluded that the St. Nicolas castle was a coastal fort that aimed mainly at protecting the harbor. Its small size prevented the hosting of the island's population during an assault.

\section{References}

[1] d'Anglure, S., Le Saint voyage de Jérusalem, Pouget-Coulon, 1858

[2] Vertot, M. A., A History of the Knights Hospitallers of St. John of Jerusalem, J. Cristie, 1818

[3] Torr, C., Rhodes in modern times, Cambridge, p.10, 1887

[4] Picenardi, G.S., Itinéraire d'un Chevalier de Saint-Jean de Jérusalem dans l'îles de Rhodes, Société de Saint Augustin, 1900

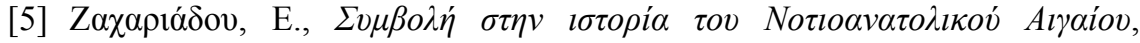

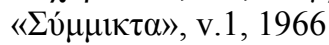

[6] Duran Duelt, D., Kastellorizo, una isla griega bajo dominio de Alfonso el Magnanimo (1450-1458): coleccion documental, CSIC Press, 2003

[7] Pinon P., Erdur K., Albert Gabriel 1883-1972: minar, arkeolog, ressam, gezin, Yapi Kredi Kulur Sanat Yayincilik Ticaret ve Sanayi, 2006

[8] Hedérer C., L'île du Château-Rouge :aperçu historique, Société d'Editions Géografiques, maritimes et coloniales, Paris, 1924 